Adam Lityński

\title{
O Podstawach ustawodawstwa karnego ZSRR z 1958 r. oraz o kodeksie karnym RSFRR z 1960 r.
}

Keywords: Soviet Law

\begin{abstract}
Summary
The destruction of Stalin's system of penal repression has been accelerated after XX Congress of the Communist Party of Soviet Union (February 1956). Substantial works on general changes in penal law were undertaken then. On December $25^{\text {th }} 1958$ the Supreme Soviet has passed The Fundamental Principles of Criminal Law of the USSR and Soviet Republics. After that, between 1959 and 1961 new criminal codes were introduced in all Soviet republics (including Russian Federation, in 1960). These legal acts were oriented on the penal prevention of socialist political system and ownership. Repression, general and individual crime prevention, resocialization (reeducation) were declared as purposes of punishment. History of Soviet Russia and USSR shows that repeating decisions of abolishing death penalty had basicly political character and were used for propaganda purposes - especially during home war. This is one of many examples of the drastic divergence between declarations and law from one side and reality on the other. "Total lie" is one of the characteristic features of the red totalitarianism (according to Leszek Kołakowski).

Penal legislation 1958-1961 can be treated as a turning point in the system of Soviet criminal law. For the first time from 1917 the legislation has approached Soviet penal law to European legal standards, by reference to neoclassical school of penal law. Despite many changes, these legal acts survived Soviet Union and created new system of Soviet penal law.
\end{abstract}


1. Demontaż stalinowskiego systemu represji karnej w obszarze ustawodawstwa karnego nabrał przyspieszenia po XX Zjeździe KPZR (luty 1956 r.), kiedy to Chruszczow w słynnym, rewelacyjnym referacie ujawnił zbrodnie stalinowskie. „Chruszczow zamienił stalinowski dualizm prawa i terroru na nowy dualizm prawa i nacisku społecznego"'; człowiek był już wolny od możliwości arbitralnego aresztowania przez tajną policję, ale niewolny od presji w miejscu zamieszkania, pracy, organizacji partyjnej - stwierdza Harold Berman². Podjęto wówczas szerzej zakrojone prace nad gruntownymi zmianami w prawie karnym, inicjując przy tym publiczną dyskusją ${ }^{3}$, co było absolutną nowością w systemie radzieckim. 25 grudnia 1958 r. Rada Najwyższa uchwaliła następujące ustawy:

1) Podstawy ustawodawstwa karnego Związku SRR i republik związkowych

2) Oodpowiedzialności karnej za przestępstwa przeciwko Państwu,

3) Oodpowiedzialności karnej za przestępstwa wojskowe,

4) Podstawy sądowego postępowania karnego Związku SRR i republik związkowych,

5) Podstawy ustawodawstwa o ustroju sądów Związku SRR, związkowych i autonomicznych republik,

6) Prawo o trybunałach wojskowych,

7) O zmianie trybu wyborów sądów ludowych .

Jeśli chodzi o prawo karne materialne, to trzy pierwsze ustawy zostały dosłownie inkorporowane do nowych kodeksów karnych poszczególnych republik związkowych. W latach 1959-1961 w każdej republice został wprowadzony w życie nowy kodeks karny ${ }^{6}$; porządkowano i systematyzowano też ogromną liczbę aktów prawnych poprzedniego okresu.

1 H. J. Berman, Justice in the U.S.S.R. An Interpretation of Soviet Law. Cambridge, Massachusetts and London [1963] (First published, 1950, under the title Justice in Russia), s. 88.

2 H. J. Berman, Justice in the U.S.S.R..., s. 88.

3 P. H. Juviler, Revolutionary Law and Order. Politics and Social Change in the USSR, New York-London 1976, s. 71 i n.

${ }_{4}$ O pierwszych radzieckich Przewodnich zasadach prawa karnego RFSRR interesująco i obszernie pisze A. Bosiacki, Utopia - władza - prawo. Doktryna i koncepcje prawne „bolszewickiej” Rosji 1917-1921, Warszawa 1999, s. 225 i n.

${ }^{5}$ Radzieckie ustawy karne i o ustroju sądów $z$ dnia 25 grudnia 1958 r. (z materiałami), Warszawa 1960; zob. też Основы уголовного законодательства Союза ССР и союзных республик, [в:] Сборник законов СССР и указов Президиума Верховного Совета СССР 1938-1975, т. 3 [bez daty wydania], s. 19: Уголовное законодательсто, s. 309-335; tеż История отечественного государства и права, ч. 2, четвертое издане, переработанное и дополненное, авторский коллектив под редакцией О. И. Чистякова, Москва 2006, s. 378-379. Zob. też H. J. Berman, Justice in the U.S.S.R..., s. 75; W. E. Butler, Soviet Law, London 1983, s. 259.

6 W układzie chronologicznym: Uzbecka SRR 21 maja 1959 r., Kazachska SRR 22 lipca 1959 r., Rosyjska SRR 27 października 1960 r., Azerbejdżańska SRR 8 grudnia 1960 r., Ukraińska SRR 29 grudnia 1960 r., Białoruska SRR 29 grudnia 1960 r., Kirgiska SRR 29 grudnia 1960 r., Gruzińska SRR 30 grudnia 1960 r., Łotewska SRR 6 stycznia 1961 r., Estońska SRR 6 stycznia 1961 r., Armeńska SRR 7 marca 1961 r., Mołdawska SRR 24 marca 1961 r., Litewska SRR 26 czerwca 1961 r., Tadżycka SRR 17 sierpnia 1961 r., 
$\mathrm{W}$ formalnie federalnym ZSRR system prawa karnego był tradycyjnie dwustopniowy. Kompetencja federalna przedstawiała się następująco: na podstawie konstytucji z 1936 r., w brzmieniu zmienionym w 1957 r. ${ }^{7}$, a później konstytucji z 1977 r. $^{8}$, do kompetencji władz centralnych (federalnych) należało wydanie aktu prawnego określającego "podstawy” m.in. ustawodawstwa karnego i republik związkowych. Taki akt prawny, pod tytułem Podstawy ustawodawstwa karnego Związku SRR i republik związkowych ${ }^{9}$, uchwalony został przez Radę Najwyższą ZSRR 25 grudnia 1958 r. Podstawy te same określiły, iż ustawodawstwo karne ZSRR składa się z Podstaw..., „Z ogólnozwiązkowych ustaw przewidujących odpowiedzialność za poszczególne przestępstwa oraz z kodeksów karnych republik związkowych." (art. 2). Ponadto Podstawy z 1958 r. rozszerzająco interpretując konstytucję ustanowiły, że do ustaw federalnych należy określenie odpowiedzialności za przestępstwa przeciwko państwu i przestępstwa wojskowe, a także „za inne przestępstwa skierowane przeciwko interesom Związku SRR” (art. 2). Prowadziło to - jak wspomniano - do prostej inkorporacji do kodeksów każdej z republik zarówno tekstów Podstaw, jak i tekstów ustaw federalnych; gdyby taka inkorporacja nie nastąpiła, wówczas ustawy te stanowiłyby samoistną podstawę odpowiedzialności. Podstawy ustawodawstwa karnego Związku SRR i republik związkowych były aktem prawnym zwięzłym, liczącym 47 artykułów.

Turkmeńska SRR 22 grudnia 1961 r. I. Andrejew, Zarys prawa karnego państw socjalistycznych, wyd. II uzupełnione, Warszawa 1979, s. 25-26.

7 Nowa konstytucja, tzw. stalinowska (1936), wniosła ważne zmiany do stanu prawnego w zakresie kompetencji federalnej oraz republikańskiej odnośnie do ustawodawstwa prawnosądowego (prawo karne, cywilne) i ustroju sądów Mianowicie prawodawstwo należące w tych materiach dotychczas do kompetencji republikańskiej (z wyjątkiem podstawowych zasad zarezerwowanych dla federacji) zastrzeżone zostało do uprawnień władz federalnych. Przewidywano wydanie kodeksu karnego wspólnego dla całego ZSRR; w związku z tym zabroniono republikom związkowym dokonywania jakichkolwiek zmian lub uzupełnień w istniejących kodeksach bez zgody władz centralnych (Prezydium Rady Najwyższej ZSRR). Nad wspólnym kodeksem pracowano w latach trzydziestych, ale jednak projekty nigdy nie uzyskały akceptacji władz politycznych i przez następnych ponad dwadzieścia lat utrzymał się stan prawny sprzed konstytucji stalinowskiej. (Zob. P. S. Romaszkin, A. A. Gercenzon, Podstawy ustawodawstwa karnego ZSRR i republik zwiazkowych, [w:] Problemy radzieckiego prawa karnego. Wybór z literatury radzieckiej. PWN, Warszawa 1962, s. 71.) 11 lutego 1957 r. Rada Najwyższa ZSRR uchwaliła ustawę o przekazaniu do kompetencji republik zwiąkowych ustawodawstwa o ustroju sądów republik zwiazkowych, uchwalania kodeksów cywilnych, karnych i postępowania sądowego; w kompetencji federalnej pozostało ustalanie podstaw (zasad) ustawodawstwa m.in. karnego. W ten sposób w zakresie prawa konstytucyjnego wrócono do stanu prawnego sprzed 1936 r., przekazując z powrotem sprawy uchwalania m.in. kodeksów karnych do kompetencji republik.

8 „Do kompetencji Związku Socjalistycznych Republik Radzieckich w osobie jego najwyższych organów władzy i administracji państwowej należy: [...] 4) zapewnienie jednolitości ustawodawstwa na całym terytorium ZSRR, ustanawianie podstaw ustawodawstwa Związku Socjalistycznych Republik Radzieckich i republik związkowych". Konstytucja Związku Socjalistycznych Republik Radzieckich, Warszawa 1977, art. 73 pkt 4.

${ }^{9}$ Основы уголовного законодательства Союза ССР и союзных республик, [w:] Сборникзаконов СССР и указов Президиума Верховного Совета СССР 1938-1975, т. 3 [bez daty wydania], s. 19: Уголовное законодательсто, s. 309-335; będę korzystał z tekstu polskiego w: Radzieckie ustawy karne i o ustroju sądów $z$ dnia 25 grudnia 1958 r. (z materiałami), Warszawa 1960. 
Kompetencja republikańska natomiast obejmowała wydawanie kodeksów każdej z republik i kodeksy te wprawdzie posiadały zarówno część ogólną, jak i szczególną, a więc były (lub mogły być) kompletne, ale w treści praktycznie dosłownie inkorporowały wspomniane Podstawy oraz obowiązujące, w praktyce najważniejsze, ustawy federalne. Ustawodawstwo federalne wykazywało przy tym silną ekspansywność; wielce rozszerzająco interpretowano cytowane przepisy o federalnym regulowaniu odpowiedzialności, wydając ustawy lub przepisy karne ogólnopaństwowe w sprawach nawet drugorzędnych, jak np. zwalczanie chorób wenerycznych. Dominacja ustawodawstwa federalnego nad republikańskim była wyraźna ${ }^{10}$.

Kodeksy republikańskie wykazywały w rezultacie daleko idącą zbieżność, a niewielkie różnice pojawiały się jedynie w części szczegółowej. Zbieżna była już sama systematyka kodeksów, które w części ogólnej składały się z pięciu rozdziałów (wyjątkowo sześciu ${ }^{11} \mathrm{w}$ wyniku podziału jednego $\mathrm{z}$ nich na dwa), zaś w części szczegółowej miały rozdziałów jedenaście (wyjątkowo dwanaście ${ }^{12}$ ). Tytuły rozdziałów były identyczne bądź bardzo zbliżone. Wszystkie kodeksy były aktami dość zwięzłymi, np. k. k. RSFRR liczył 269 artykułów ${ }^{13}$. Niewielkie odmienności w częściach szczegółowych kodeksów wynikały albo ze specyfiki kulturowej, albo położenia geograficznego. W ten sposób osiągano daleko idącą jedność ustawodawstwa karnego (i nie tylko) na terenie całego ZSRR: przy formalnej decentralizacji i samodzielności republik, faktyczna daleko idąca centralizacja, co akurat $\mathrm{w}$ przedmiocie prawa karnego należy uznać za pożyteczne i trafne z punktu widzenia praworządności. Tendencje centralizacyjne wzmogły się zwłaszcza po wprowadzeniu w życie konstytucji „breżniewowskiej” z 1977 r., z którą wiązano tezę o powstaniu jednolitego narodu radzieckiego i wówczas też pojawiły się głosy uzasadniające celowość całkowitego zunifikowania prawa karnego w ZSRR i wydania jednego kodeksu karnego ${ }^{14}$.

Dalsze uwagi na temat prawa karnego będą oparte na Podstawach... i kodeksie karnym Rosyjskiej SFRR.

${ }^{10}$ Według danych na koniec lat siedemdziesiątych, w kodeksie karnym Rosji (k.k. RSFRR z 27 października 1960 r.) uległo zmianie $42 \%$ wszystkich przepisów w stosunku do stanu pierwotnego, przy czym 77\% zmian części ogólnej i 60\% zmian części szczegółowej było efektem federalnej działalności ustawodawczej. M. Filar, W stużbie utopii. 73 lata radzieckiego prawa karnego, Toruń 1992, s. 41.

${ }^{11}$ K.k. RSFRR, Tadżyckiej, Estońskiej.

${ }^{12}$ K.k. RSFRR oraz Armeńskiej.

${ }^{13}$ Kodeks karny RSFRR. Kodeks karnoprocesowy RSFRR. Ustawa o ustroju sąów RSFRR, tłum. L. Hochberg, Warszawa 1961.

${ }^{14}$ M. Filar, W stużbie utopii..., s. 42. 
2. Podstawy ustawodawstwa karnego Związu SRR i republik związkowych ${ }^{15}$ z 1958 r., a za nimi dokładnie tak samo k.k. RSFRR ${ }^{16}$, eksponowały w pierwszych artykułach zadania prawa karnego, akcentując ochronę ustroju i własności socjalistycznej, a interesy jednostki wymieniając w dalszej kolejności: „Zadaniem kodeksu karnego RSFRR jest ochrona przed zamachami przestępnymi radzieckiego ustroju społecznego i państwowego, własności socjalistycznej, jednostki i praw obywateli oraz całego socjalistycznego porządku prawnego." (art. 1 Podstaw... i art. 1 k.k. RSFRR). Ujęcie było więc tradycyjne dla prawa radzieckiego ${ }^{17}$, chociaż redakcja przepisu była bardziej kompleksowa.

Tenże art. 1 Podstaw... i art. 1 k.k. RSFRR ponadto wykluczał do tego czasu obowiązującą w prawie radzieckim analogię ${ }^{18}$, stanowiąc iż to „kodeks karny RSFRR określa, które społecznie niebezpieczne czyny są czynami przestępnymi, i ustala kary, jakie mają być stosowane wobec sprawców przestępstw." (art. 1 k.k. RSFRR). Było to ustanowienie nowych w prawie radzieckim zasad nullum crimen, nulla poena sine lege, zaś ich wyeksponowanie w pierwszym artykule jest znamienne ${ }^{19}$. Później zasady te trafiły do konstytucji „breżniewowskiej” z $1977 \mathrm{r} .^{20}$ Uzupełniająca zasada lex retro non agit zawarta została $\mathrm{w}$ art. 6 zarówno Podstaw ustawodawstwa karnego Zwiąku SRR i republik związkowych, jak i k.k. RSFRR ${ }^{21}$. Zlikwidowana została w ten sposób analogia w prawie karnym, która przez kilkadziesiąt lat była uważana za niezbędną instytucję socjalistycznego prawa karnego ${ }^{22}$.

15 Основы уголовного законодательства Союза ССР и союзных республик, [w:] Сборник законов СССР и указов Президиума Верховного Совета СССР 1938-1975, т. 3 [bez daty wydania], s. 19: Уголовное законодательсто, s. 309-335; będę korzystał z tekstu polskiego w: Radzieckie ustawy karne i o ustroju sądów z dnia 25 grudnia 1958 r. (z materiałami), Warszawa 1960.

${ }^{16}$ Tekst polski w: Kodeks karny RSFRR. Kodeks karnoprocesowy RSFRR. Ustawa o ustroju sqadów RSFRR, tłum. L. Hochberg, Warszawa 1961.

${ }^{17}$ W. E. Butler, Soviet Law..., s. 260; zob. V. M. Chkhikvadze [Czikwadze], The Soviet State and Law, translated by Y. Sdobnikov, Honolulu, Hawaiit 2000, s. 258.

${ }^{18}$ Zob. A. Bosiacki, Utopia - władza - prawo..., s. 230.

${ }^{19}$ Oceniane jako wielki krok naprzód w postalinowskiej reformie prawa karnego. W. E. Butler, Soviet Law..., s. 262; zob. też V. M. Chkhikvadze [Czikwadze], The Soviet State and Law..., s. 259.

${ }^{20}$ Art. 160: „Nikt nie może być uznany za winnego popełnienia przestępstwa i skazany w postępowaniu karnym inaczej niż wyrokiem sądu i zgodnie z ustawą." Konstytucja Związku Socjalistycznych Republik Radzieckich, Warszawa 1977.

${ }^{21}$ „Przestępność i karalność czynu określa ustawa obowiązująca w czasie dokonania tego czynu. Ustawa uchylająca karalność czynu lub łagodząca karę działa wstecz, tj. obowiązuje również co do czynów dokonanych przed jej wydaniem. Ustawa wprowadzająca karalność czynu lub surowszą karę nie ma mocy wstecznej." Art. 6 k.k. RSFRR.

${ }^{22} \mathrm{~W}$ obowiązującym do tego czasu k.k. RSFRR z 1926 r. istniał przepis: „Jeśli jakiekolwiek społecznie niebezpieczne działanie nie jest wprost przewidziane w kodeksie niniejszym, wówczas zasadę i zakres odpowiedzialności za nie określa się zgodnie z tymi artykułami kodeksu, które przewidują przestępstwa najbardziej podobne co do rodzaju." (art. 16). W kodeksie z 1926 r. powtórzona została za k.k. RSFRR z 1922 r. klasyczna analogia legis jako zasada kodeksowa. Kodeks karny Rosji sowieckiej 1927, tłum. i wstęp R. Lemkin, Przedmowa W. Makowski, Warszawa 1928. Tłumaczenie zostało zmodernizowane przeze mnie - A.L. 
Definicja przestępstwa, sformułowana $\mathrm{w}$ art. 7 zarówno Podstaw..., jak i k.k. RSFRR, łączyła w sobie elementy definicji materialnej i formalnej. W rozwlekłej formie słownej oba akty definiowały przestępstwo jako „przewidziany w ustawie karnej czyn społecznie niebezpieczny (działanie lub zaniechanie)" (Podstawy...), godzący w radziecki ustrój społeczny, państwowy lub gospodarczy, we własność socjalistyczną, w osobę, w prawa obywateli „oraz każdy inny czyn społecznie niebezpieczny, godzący w socjalistyczny porządek prawny, a przewidziany w części szczegółowej” kodeksu (k.k. RSFRR). Dalej przepis art. 7 obu aktów stanowił, że nie jest przestępstwem czyn, który wprawdzie formalnie wyczerpuje znamiona opisane w kodeksie, ale z uwagi „na swą nieznaczną wagę nie stanowi społecznego niebezpieczeństwa". Była to logiczna konsekwencja definicji przestępstwa zawierającej cechy materialne: jeżeli coś nie jest społecznie niebezpieczne, to nie jest przestępstwem, bo przestępstwo to czyn społecznie niebezpieczny.

Komunistyczny teoretyk prawa tak wyjaśniał istotę materialnego ujmowania przestępstwa: „W doktrynie prawa karnego w państwach socjalistycznych materialne ujęcie przestępstwa jako czynu społecznie niebezpiecznego ma dwojakie znaczenie: teoretyczno-poznawcze i praktyczne. Z punktu widzenia teoretycznego takie ujęcie wskazuje na związek przestępstwa z życiem społecznym, ale rozumianym $\mathrm{w}$ myśl zasad materializmu historycznego o klasowej strukturze społeczeństwa [...]. Określając przestępstwo jako czyn społecznie niebezpieczny, nauka prawa przeciwstawia się metafizycznym koncepcjom o przestępstwie, jak o naruszeniu praw natury, postępowaniu sprzecznym z wolą boską, niezgodnym z odwiecznymi nakazami etyki itd. [...] Opierając się na założeniach materializmu historycznego, nauka ta upatruje istotną cechę przestępstwa w tym, że jest ono niebezpieczne dla stosunków społecznych odpowiadających interesom klasy panującej. Klasa panująca za pomocą swojego aparatu władzy państwowej określa, które czyny są społecznie niebezpieczne i jak powinny one być ścigane i karane. W tym znaczeniu mówi się, że przestępstwo jest zjawiskiem klasowym. Początki materialnego ujęcia przestępstwa datują się od zarania prawa radzieckiego"23.

Obok elementów materialnego oraz formalnego definicji przestępstwa, trzeci element definicji przestępstwa znajdował się - identycznie w Podstawach ustawodawstwa karnego Związku SRR i republik zwiazkowych, jak i k.k. RSFRR $\mathrm{w}$ art. 3, stanowiącym, iż podstawą odpowiedzialności karnej jest wina ${ }^{24}$, a więc czynnik subiektywny. Przez co najmniej dwie dekady po 1917 r. radziecka jurysprudencja była bardzo krytyczna wobec koncepcji winy, akcentując społecz-

${ }^{23}$ I. Andrejew, Zarys prawa karnego..., s. 79-80.

${ }^{24}$ Art. 3. „Podstawy odpowiedzialności karnej. Odpowiedzialności karnej i karze podlega tylko osoba winna popełnienia przestępstwa, czyli osoba, która umyślnie lub przez nieostrożność popełniła społecznie niebezpieczny czyn, określony w ustawie karnej. Karę stosuje tylko z mocy wyroku sądu”" Kodeks karny RSFRR. Kodeks karnoprocesowy RSFRR. Ustawa o ustroju sądów RSFRR, tłum. L. Hochberg, Warszawa 1961. 
ne niebezpieczeństwo tkwiące $\mathrm{w}$ czynie i w osobie, oceniane $\mathrm{z}$ punktu widzenia klasowego ${ }^{25}$. Zmiana wynikała zarówno z ustawy karnej, jak i była już wówczas uznawana przez zdecydowaną większość teoretyków prawa karnego oraz konsekwentnie realizowana w orzecznictwie. W wytycznych (z 18 marca 1963 r.) Sąd Najwyższy RSFRR wskazał, że „sądy powinny poświęcać szczególną uwagę stronie subiektywnej przestępstwa" ${ }^{26}$. Wina to filar szkoły klasycznej, ale w prezentowanym kodeksie rosyjskim obok pojawił się jeszcze element $\mathrm{z}$ nauk kierunku socjologicznego: otóż k.k. RSFRR (art. 50) stanowił, iż sąd może uwolnić od odpowiedzialności sprawcę, jeżeli ten „przestał być społecznie niebezpieczny”.

W art. 8 - zarówno Podstaw ustawodawstwa karnego Związku SRR i republik związkowych, jak i k.k. RSFRR - wina umyślna sformułowana została $\mathrm{w}$ postaciach zamiaru bezpośredniego (dolus directus) oraz zamiaru ewentualnego (dolus eventualis). Zamiar bezpośredni miał miejsce, gdy „sprawca był świadom społecznego niebezpieczeństwa swojego działania lub zaniechania, przewidywał jego społecznie niebezpieczne skutki oraz ich chciał albo świadomie godził się na ich nastąpienie". Natomiast wina nieumyślna (w k.k. nazwana „nieostrożnym popełnieniem przestępstwa”) sformułowana została (art. 9 obu aktów) w postaciach, które w polskiej tradycji prawa karnego (por. polski k.k. z 1932 r.) nazywamy lekkomyślnością (luxuria) oraz niedbalstwem (negligentia). Lekkomyślność miała miejsce wówczas, gdy „sprawca przewidywał możliwość nastąpienia społecznie niebezpiecznych skutków swego działania lub zaniechania, lecz lekkomyślnie przypuszczał, że im zapobiegnie”, zaś niedbalstwo określone zostało jako sytuacja, gdy sprawca nie przewidywał możliwości wystąpienia społecznie niebezpiecznych skutków swojego działania, „chociaż powinien był i mógł je przewidzieć”. W k.k. niezbyt szczęśliwie postawiono powinność przewidzenia skutków przed możliwością ich przewidzenia, mimo że w Podstawach... kolejność była prawidłowa; ale to szczegół natury redakcyjnej. W sumie konstrukcja winy w Podstawach ustawodawstwa karnego Związku SRR i republik związkowych, jak i k.k. RSFRR, analogicznie w innych kodeksach republikańskich, które zgodnie powtarzały instytucje i rozwiązania Podstaw..., odpowiadała standardom zachodnioeuropejskim, chociaż łatwo zauważyć dość natrętne stałe eksponowanie społecznego niebezpieczeństwa czynu, czyli materialnej przesłanki przestępstwa. Można dostrzec też wyraźne podobieństwo do rozwiązań polskiego k.k. z $1932 \mathrm{r}^{27}$, ale trochę także do k.k. rosyjskiego z 1903 r. (tzw. kodeksu Tagacewa).

${ }^{25}$ H. J. Berman, Justice in the U.S.S.R..., s. 252; zob. też W. E. Butler, Soviet Law..., s. 262; P. H. Juviler, Revolutionary Law..., s. 74.

${ }^{26}$ Cyt. za Filar M., W stużbie utopii..., s. 44.

${ }^{27}$ Jak wiadomo, główny twórca części ogólnej polskiego k.k. z 1932 r., profesor Uniwersytetu im. Jana Kazimierza we Lwowie - Juliusz Makarewicz, pozostał po II wojnie w swoim ukochanym Lwowie, a władze radzieckie doceniły jego wielkość naukową i wyjątkowo zezwoliły mu na wykładanie na ukraińskim już Uniwersytecie im. Iwana Franki we Lwowie. J. Makarewicz zmarł we Lwowie w 1955 r. 
Każde przestępstwo można było popełnić zarówno z winy umyślnej, jak i nieumyślnej, jeżeli tylko istota czynu nie była z tym sprzeczna. Tego rodzaju rozwiązanie ma swoje wyraźnie złe strony, polegające na zwiększeniu możliwości manipulacji interpretacyjnych. Brak rozgraniczenia możliwości popełnienia niektórych przestępstw tylko z winy umyślnej, a niektórych zarówno umyślnie, jak i nieumyślnie, wiązał się $\mathrm{z}$ faktem, iż prawo radzieckie nie znało formalnej klasyfikacji czynów przestępnych w zależności od zagrożenia sankcją (np. upowszechniony w Europie schemat napoleoński podziału na zbrodnie, występki i wykroczenia), a więc nie było możliwe skonstruowanie, że np. zbrodnie można popełnić tylko umyślnie, a inne zarówno umyślnie, jak i nieumyślnie (tak polski k.k. z 1932 r.). Nie wynikało to z przeoczenia, ale z poglądu radzieckiej doktryny o jednorodności przestępstw, co przeczy ich klasyfikacji. Wbrew temu poglądowi wkrótce po rewolucji choćby nieformalnie przestępstwa dzielono na dwie kategorie, a to należące do właściwości bądź sądu ludowego, bądź trybunału rewolucyjnego.

W programie XXII Zjazdu KPZR (październik 1961 r.) zawarta została teoria rozwarstwienia przestępczości i dyferencjacji reakcji na nią, która uzyskała rangę oficjalnego programu polityczno-kryminalnego ${ }^{28}$. Rozwarstwienie przestępczości, a bardziej jeszcze dyferencjacja sprawców i stosowanych środków karnych $\mathrm{w}$ istocie - bez ustawowego sprecyzowania - prowadzone były w Rosji radzieckiej i ZSRR od początku zdobycia przez bolszewików władzy. Szczególnie zaraz po wydarzeniach 1917 r., a także w okresie stalinowskim, zróżnicowanie represji karnej bardzo silnie wiązano z osobą sprawcy, a nie z czynem. Epigon poprzedniego systemu albo inny człowiek pochodzenia źle widzianego w państwie proletariatu („burżuj”, kułak itp.) nie tylko podlegał karze znacznie surowszej, ale jakże często spotykała go surowa represja pre-deliktualna (przed popełnieniem przestępstwa a ściślej - bez popełnienia jakiegokolwiek przestępstwa). Taka dyferencjacja represji karnej nosiła charakter pseudopozytywistyczny, ukierunkowany na czynniki tkwiące w osobie sprawcy. M. Filar twierdzi, że logiczną bazą koncepcji rozwarstwienia przestępczości i reakcji na nią była stworzona jeszcze w 1918 r. przez Lenina teoria reliktów. Istota teorii reliktów streszczała się następująco: $w$ warunkach nowego znakomitego ustroju nie ma ontologicznych podstaw do rozwoju przestępczości. Wobec tego istnienie przestępczości da się wytłumaczyć: a) bądź to złośliwą działalnością wrogów ustroju, b) bądź to stanowi relikt dawnej epoki tkwiący w mentalności ludzi pozytywnie ustosunkowanych do nowego ustroju. W rezultacie reakcja na tak rozwarstwioną ontologicznie przestępczość musi być stosownie zróżnicowana. Tych pierwszych należy karać surowo; drugich łagodnie i reedukacyjnie, przy szerokim udziale społeczeństwa. Prowadziło to do polaryzacji polityki karnej i utraty złotego środka.

${ }^{28}$ M. Filar, W służbie utopii..., s. 32; W. E. Butler, Soviet Law..., s. 260. 
Dopiero znacznie później, po okresie stalinowskim, powoli dyferencjację zaczęto wiązać $\mathrm{z}$ czynem przestępnym, a nie z osobą. Efektem były nowelizacje zarówno Podstaw ustawodawstwa karnego Związku SRR i republik związkowych, jak i k.k. RSFRR, w tym wprowadzenie pojęcia ciężkiego przestępstwa, opartego na kryterium wskazania go w znowelizowanym przepisie (w sumie około 50 przestępstw), a zwłaszcza liczne ważne zmiany w $1961 \mathrm{r}$. dokonane przede wszystkim dekretem o wzmożeniu walki ze szczególnie niebezpiecznymi przestępstwami ${ }^{29} \mathrm{i}$ innymi aktami prawnymi ${ }^{30}$. Względem sprawców czynów wymienionych $\mathrm{w}$ znowelizowanym prawie karnym ${ }^{31}$ zaostrzono sankcje karne przez szerokie dopuszczenie stosowania kary śmierci oraz podwyższenie progów kary pozbawienia wolności, zniesienie możliwości warunkowego przedterminowego zwolnienia, możliwość orzeczenia dodatkowej kary zesłania na okres od 2 do 5 lat $^{32}$, także w zakresie rygoru odbywania kary i inne.

Polityka rozwarstwienia przestępczości, podjęta w ZSRR na początku lat sześćdziesiątych, przyniosła jednocześnie złagodzenie sankcji za drobne przestępstwa pospolite, a zwłaszcza wprowadzenie środków oddziaływania społecznego, środków administracyjnych i dyscyplinarnych - w miejsce kar kryminalnych za czyny, które do tego czasu były przestępstwami. Były to wskazane w kodeksie (art. 51 pkt 1 i 2) czyny drobne (np. lekkie uszkodzenie ciała, szkalowanie, zniewagi), w których to przypadkach kodeks dawał sądowi możliwość uwolnienia od odpowiedzialności karnej i przekazania sprawy sądowi koleżeńskiemu. Taką samą możliwość uzyskał sąd, gdy miało miejsce „inne przestępstwo nieznacznej wagi, jeżeli na podstawie rodzaju popełnionego czynu i osobowości sprawcy można wnioskować, że ulegnie on poprawie bez wymierzenia kary wskutek zastosowania środków oddziaływania społecznego" (art. 51 pkt 3 k.k. RSFRR). Stworzono także możliwość uwolnienia niektórych sprawców od odpowiedzial-

${ }^{29}$ Dekret Prezydium Rady Najwyższej ZSRR z 5 maja 1961 r. o wzmożeniu walki ze szczególnie niebezpiecznymi przestępstwami, [w:] Kodeks karny RSFRR. Kodeks karnoprocesowy RSFRR. Ustawa o ustroju sądów RSFRR, tłum. L. Hochberg, Warszawa 1961, s. 129-132

${ }^{30}$ Wymienia je I. Andrejew, Zarys prawa karnego..., s. 202.

${ }^{31}$ „[...] ustalić treść artykułu 22 Podstaw ustawodawstwa karnego Związu SRR i republik związkowych w następującej redakcji: «Dopuszcza się stosowanie kary śmierci - rozstrzelania - jako kary wyjątkowej, aż do jej zupełnego zniesienia, za zdradę ojczyzny, szpiegostwo, dywersję, akt terrorystyczny, bandytyzm, za wyrabianie w celu puszczenia w obieg lub puszczanie w obieg fałszywych pieniędzy i papierów wartościowych, dokonywane zawodowo, za umyślne zabójstwo w okolicznościach obciążających określonych w przepisach ustaw karnych Związku SRR i republik związkowych, przewidujących odpowiedzialność za umyślne zabójstwo, za zagarnięcie mienia państwowego lub społecznego w szczególnie dużych rozmiarach, a w czasie pokoju lub w sytuacji bojowej - również za inne szczególnie ciężkie przestępstwa w wypadkach wyraźnie przewidzianych w ustawodawstwie Związku SRR.

Stosowanie kary śmierci - rozstrzelania - jest dopuszczalne także w stosunku do szczególnie niebezpiecznych recydywistów i osób skazanych za ciężkie przestępstwa, terroryzujących w miejscach odbywania kary pozbawienia wolności [...]»". Dekret Prezydium Rady Najwyższej ZSRR z 5 maja 1961 r. o wzmożeniu walki ze szczególnie niebezpiecznymi przestępstwami..., s. 129-130.

${ }^{32}$ Dekret Prezydium Rady Najwyższej ZSRR z 5 maja 1961 r. o wzmożeniu walki ze szczególnie niebezpiecznymi przestępstwami..., s. 129-132. 
ności i oddania „na porękę” organizacji społecznej lub zespołu pracowniczego w celu reedukacji, jeżeli popełnione przestępstwo i sam sprawca nie stanowią większego niebezpieczeństwa społecznego" (art. 52 k.k. RSFRR). Wyobrażano sobie, że będzie to także forma aktywizacji społeczeństwa, co znalazło swój wyraz w uchwale KC KPZR i Rady Ministrów ZSRR (z 2 marca 1959 r.) „o udziale ludzi pracy w ochronie porządku społecznego w kraju”; wówczas (1959 r.) też wszczęto dużą propagandową dyskusję nad projektem ustawy „o podniesieniu roli społeczeństwa $\mathrm{w}$ walce $\mathrm{z}$ naruszeniami radzieckiej praworządności i reguł współżycia socjalistycznego" (której nigdy nie uchwalono), a także nad wzorcowymi regulaminami sądów koleżeńskich i innymi. W 1977 r. wprowadzono za przestępstwo możliwość zastosowania sankcji administracyjnych zamiast kary: w sprawach, za które ustawa nie przewidywała kary surowszej od jednego roku pozbawienia wolności można było orzec sankcję administracyjną, a to grzywnę do 50 rubli, pracę poprawczą w miejscu zatrudnienia sprawcy do 2 miesięcy z możliwością potrącenia $20 \%$ wynagrodzenia, areszt do $15 \mathrm{dni}$. Sankcja administracyjna nie pociągała za sobą skutków skazania ${ }^{33}$.

Założenia polityki kryminalnej - polityki rozwarstwienia reakcji na przestępczość - zawarte zostały w uchwale prezydium Rady Najwyższej ZSRR z lutego 1977 r.: „[...] należy wykorzystać możliwości poprzez zdyferencjonowanie wymiaru kary i praktyki jej wykonania, by sprawców nie izolować od społeczeństwa i dla mniej niebezpiecznych przestępstw rozszerzyć możliwości stosowania środków oddziaływania administracyjnego i społecznego, równocześnie nie rozmontowując środków karnych stosowanych wobec niebezpiecznych przestępców"34.

W ten sposób, chociaż Podstawy ustawodawstwa karnego Związku SRR i republik zwiazkowych ani k.k. RSFRR nie przeprowadzały formalnego podziału przestępstw, to jednak można zauważyć wytworzenie się ich czterech rodzajów: 1) ciężkie przestępstwa, 2) zwykłe przestępstwa, 3) drobne przestępstwa, 4) przestępstwa nieznacznej wagi (o małym stopniu społecznego niebezpieczeństwa czynu), jeżeli sprawca nie stanowi większego niebezpieczeństwa. Może zrodzić się pytanie, dlaczego doszło do faktycznego podziału (klasyfikacji) przestępstw, chociaż doktryna, a w ślad za tym ustawodawca tego unikali, zaprzeczając takiej potrzebie. Przyczyna tkwi w podjęciu świadomych kroków w kierunku rozwarstwienia przestępczości i represji karnej, przy jednoczesnym coraz wyraźniejszym odchodzeniu od karania przede wszystkim osoby w kierunku nacisku na czyn jako podstawę odpowiedzialności. Przez dwadzieścia porewolucyjnych lat w prawniczym i prawnym obiegu nie funkcjonowały pojęcia „winy" $i$,kary”, wyeliminowane przez „społeczne niebezpieczeństwo” i „środki obrony społecznej”,

\footnotetext{
${ }^{33}$ I. Andrejew, Zarys prawa karnego..., s. 206.

${ }^{34}$ Cyt. za M. Filar, W stużbie utopii..., s. 36.
} 
ale zaczęły się one znowu stopniowo pojawiać w połowie lat trzydziestych ${ }^{35}$. Jest w tym odwrót od koncepcji pozytywistycznych, socjologicznych, w kierunku zasad szkoły klasycznej prawa karnego i jest też przejaw tendencji do zbliżenia się do praworządności w europejskim rozumieniu tego pojęcia. Jednak w $1961 \mathrm{r}$. w programie KPZR akcentowano prewencję w prawie karnym ${ }^{36}$.

Okolicznościami wyłączającymi winę były niepoczytalność i nieletniość. Niepoczytalność została zdefiniowana jako stan, gdy osoba w chwili popełnienia czynu społecznie niebezpiecznego „nie mogła sobie zdawać sprawy ze swego postępowania lub kierować nim na skutek trwałej choroby psychicznej, czasowego zakłócenia czynności psychicznej lub niedorozwoju umysłowego albo innego stanu chorobowego" (art. 11 Podstaw...) $)^{37}$. W stosunku do takiej osoby sąd mógł orzec zastosowanie przymusowych środków leczniczych ${ }^{38}$, a to umieszczenie w szpitalu psychiatrycznym typu ogólnego albo specjalnego, czyli pod wzmożonym nadzorem (art. 58-60 k.k.). Umieszczenie było oczywiście bez określenia terminu, a sąd uchylał decyzję po wyzdrowieniu. Prawo radzieckie nie znało natomiast instytucji poczytalności ograniczonej. Zamknięcie w szpitalu psychiatrycznym - w „psychuszce” - było stosowane od dawna ${ }^{39}$, ale od lat sześćdziesiątych niemal do końca ZSRR przybrało dużą skalę ${ }^{40}$. Stosowane było także wobec szczególnie niesfornych opozycjonistów-dysydentów, osób z kręgów kultury, nauki ${ }^{41}$. Pozostający na usługach władz psychiatrzy wymyślili chorobę „schizofrenię bezobjawową” oraz „kompleks reformatorstwa ${ }^{42}$ ”. Pozwalało to na eliminowanie dysydentów bez kłopotliwego karnego postępowania dowodowego i - niby - zachowanie twarzy na forum międzynarodowym.

Pełnej odpowiedzialności karnej podlegały osoby, które ukończyły 16 lat ${ }^{43}$. Od lat 14 pełnej odpowiedzialności karnej podlegał nieletni w wypadku enumeratywnie wymienionych ciężkich przestępstw (zabójstwo, zgwałcenie, spo-

${ }^{35}$ H. J. Berman, Justice in the U.S.S.R..., s. 252.

${ }^{36}$ W. E. Butler, Soviet Law..., s. 260.

${ }^{37}$ K.k. RSFRR był trochę mniej precyzyjny: ,nie mogła zdawać sobie sprawy ze swych czynów ani nimi pokierować na skutek chronicznej choroby psychicznej, niedorozwoju lub innego stanu chorobowego" (art. 11 k.k. RSFRR).

${ }^{38}$ Zob. bliżej W. E. Butler, Soviet Law..., s. 269 i n.

${ }^{39}$ H. J. Berman, Justice in the U.S.S.R..., s. 312 i n., zwłaszcza s. 315 i n.; zob. też P. H. Juviler, Some Trends in Soviet Criminal Justice, [in:] Soviet Law after Stalin, ed. by Donald D. Barry, George Ginsburgs and Peter B. Maggs, part III: Soviet Institutions and the Administration of Law. Alphen aan den Rinn-The Netherlands and Germantown-Maryland 1979, s. 61.

${ }^{40}$ Zob. zwłaszcza W. Bukowski, I powraca wiatr..., tłum. A. Mietkowski, Kraków 1999, s. 189-217 i passim.

${ }^{41}$ M. Filar wypowiedział nawet zdanie, iż „doprowadziło to do uczynienia w krótkim czasie z radzieckich "psychuszek» najbardziej ekskluzywnych salonów literacko-politycznych ZSRR" (M. Filar, W stużbie utopii..., s. 33), co jednak należy traktować jako pewną przenośnię. Warunki pobytu w „psychuszkach" były uciążliwe, a nawet drastycznie brutalne. Zob. W. Bukowski, I powraca wiatr..., s. 189-217 i passim.

${ }^{42}$ M. Filar, $W$ stużbie utopii..., s. 33.

${ }^{43}$ W. E. Butler, Soviet Law..., s. 264; zob. też P. H. Juviler, Revolutionary Law..., s. 74. 
wodowanie katastrofy i licznych innych (art. 10 obu aktów). Jeżeli jednak nieletni (do lat 18) popełnił czyn o małym stopniu społecznego niebezpieczeństwa i rokuje poprawę, to sąd mógł zastosować „środki przymusowe o charakterze wychowawczym", a mianowicie zobowiązać do przeproszenia pokrzywdzonego, wynagrodzenia wyrządzonej szkody, orzec naganę, surową naganę, upomnienie, oddać pod dozór rodziców lub opiekunów, skierować do kolonii wychowawczej $\mathrm{i}$ inne (art. 63); owe kolonie wychowawcze przedstawiały obraz żałosny i były $\mathrm{w}$ istocie rodzajem obozu-łagru dla dzieci ${ }^{44}$. W $1977 \mathrm{r}$. wprowadzono dla nieletnich instytucję odroczenia wykonania wyroku. Jeżeli nieletni w ogóle nie podlegał odpowiedzialności karnej, a popełnił czyn karalny, postępowanie odbywało się przed społecznymi komisjami do spraw nieletnich, funkcjonującymi przy organach administracji terenowej (komitetach wykonawczych miejscowych rad). Generalnie nastąpiło zdecydowane złagodzenie represji karnej wobec nieletnich.

Kwestia odpowiedzialności karnej osoby popełniającej czyn karalny w stanie upojenia alkoholowego od dawna sprawiała pewien kłopot teoretykom i praktykom. Trudność polega na zagadnieniu pogodzenia zasady winy jako podstawy odpowiedzialności (wszak przy pełnym opilstwie winy brak) z potrzebą ochrony społeczeństwa. Nowe radzieckie prawo karne postawiło sprawę kategorycznie: „Osoba, która popełniła przestępstwo w stanie nietrzeźwym, nie jest wolna od odpowiedzialności karnej” (art. 12 Podstaw... ${ }^{45}$. Żadnych wyjątków.

Zarówno Podstawy ustawodawstwa karnego Związku SRR i republik związkowych, jak i k.k. RSFRR, znały obronę konieczną i jej przekroczenie (art. 13 obu aktów), jak również stan wyższej konieczności (art. 14), skonstruowane $\mathrm{w}$ sposób typowy dla prawa europejskiego ${ }^{46}$, ale $\mathrm{z}$ zaakcentowaniem ochrony interesów państwa radzieckiego przed interesami indywidualnymi.

Obok usiłowania, skonstruowanego w postaci europejskiej, prawo radzieckie znało postać stadialną przygotowania do popełnienia przestępstwa, za które uważano „nabycie lub przysposobienie środków bądź narzędzi albo inne umyślne stworzenie warunków do popełnienia przestępstwa” (art. 15 obu aktów). Podobnie jak usiłowanie, przygotowanie (art. 15) było możliwe we wszystkich przypadkach, jeśli tylko wchodziło $\mathrm{w}$ grę pojęciowo. Kara za przygotowanie i usiłowanie groziła taka, jak za dokonanie.

Szeroko skonstruowane było „współuczestnictwo” w przestępstwie, do czego zaliczono współsprawstwo, sprawstwo kierownicze („organizator”), podżeganie i pomocnictwo. Podobny charakter miało, ale sklasyfikowane było oddzielnie,

${ }^{44}$ F. J. M. Feldbrugge, Soviet Corrective Labor Law, [in: ]Soviet Law after Stalin, ed. by Donald D. Barry, George Ginsburgs and Peter B. Maggs, part I: The Citizen and the State in Contemporary Soviet Law, Leyden 1977, s. 36, 41 i n.

${ }^{45}$ „Nie uwalnia od odpowiedzialności karnej popełnienie przestępstwa w stanie upicia się"(art. 12 k.k. RSFRR).

${ }^{46}$ W. E. Butler, Soviet Law..., s. 265 i n. 
poplecznictwo („ukrywanie” - art. 18 obu aktów i 189 k.k. RSFRR) oraz specyficzne dla prawa radzieckiego niedoniesienie, zaniechanie denuncjacji (art. 19 obu aktów i 190 k.k. RSFRR); oba czyny karane tylko w wypadkach wskazanych w ustawie.

Przepisy o systemie kar zawsze dają szczególnie ważny obraz prawa karnego. Jako cel kary werbalnie deklarowano represję, prewencję ogólną i szczególną oraz poprawę i resocjalizację (reedukację ${ }^{47}$ ) (art. 20 obu aktów). Długi katalog kar w Podstawach... wyglądał następująco ${ }^{48}$ :

\section{1)Kary zasadnicze:}

1.1. pozbawienie wolności: wymierzane być mogło do 10 lat, a w wypadkach przewidzianych w ustawach, „Za szczególnie ciężkie przestępstwa i w stosunku do szczególnie niebezpiecznych recydywistów" do 15 lat; skazani odbywali tę karę „w kolonii pracy poprawczej lub w więzieniu, a niepełnoletni - w kolonii pracy dla niepełnoletnich";

${ }^{47}$ Ibidem, s. 266.

${ }^{48}$ W szczegółach zachodziły różnice między Podstawami... a k.k. W tekście referuję według Podstaw..., natomiast poniżej katalog kar według k.k. RSFRR z 1960 r.:

1) kary zasadnicze:

1.1. pozbawienie wolności: wymierzana być mogła od 3 miesięcy do 10 lat, a recydywistom do 15 lat; w razie zamiany kary śmierci może ta zamiana być dokonana na karę pozbawienia wolności 20 lat;

1.2. praca poprawcza bez pozbawienia wolności: k.k. RSFRR przewidywał ją w wymiarze od 1 miesiąca do 1 roku, z wynagrodzenia skazanego potrącało się 5-20\%;

1.3. nagana społeczna; „polega na tym, że sąd publicznie ogłasza udzieloną sprawcy naganę, w wypadkach koniecznych podaje się tę wiadomość społeczeństwu za pomocą prasy lub w inny sposób" (art.33);

1.4. skierowanie do oddziału karnego, w stosunku do wojskowych;

1.5. umieszczenie w profilaktorium pracy wychowawczej - w stosunku do włóczęgów, żebraków, pasożytów, nie płacących alimentów (kara dodana w 1982 r.);

2) kary zasadnicze albo dodatkowe:

2.1. zesłanie: „polega na wydaleniu skazanego $\mathrm{z}$ miejsca jego zamieszkania $\mathrm{z}$ obowiązkiem osiedlenia się w określonej miejscowości" (art. 25), wymierzane na okres 2-5 lat;

2.2. wysiedlenie: „polega na wydaleniu skazanego z miejsca jego zamieszkania z zakazem zamieszkiwania w określonych miejscowościach" na okres 2-5 lat (art. 26);

2.3. pozbawienie prawa zajmowania określonych stanowisk lub wykonywania określonej działalności na czas 1-5 lat;

2.4. grzywna (art. 30): wymierzana w wysokości wskazanej w konkretnych przepisach karnych, w zasadzie w wysokości od 50 do 300 rubli, wyjątkowo do 1000 rubli; długo sądy były jej niechętne i rzadko stosowały (10\% skazań), bowiem obarczano ją odium kary burżuazyjnej; zamiana grzywny na karę pozbawienia wolności była niedopuszczalna;

2.5. zwolnienie ze stanowiska służbowego;

2.6. nałożenie obowiązku naprawienia wyrządzonej szkody (zadośćuczynienie): mogła polegać na pokryciu straty majątkowej albo na przeproszeniu pokrzywdzonego;

3) kary dodatkowe:

3.1. konfiskata mienia: mogła być orzeczona konfiskata całości lub części mienia; tylko za przestępstwa przeciwko państwu oraz z chęci zysku;

3.2. pozbawienie stopnia wojskowego lub tytułu specjalnego;

4) kara śmierci, określona jako kara wyjątkowa. 
1.2. zesłanie: „polega na wydaleniu skazanego z miejsca jego zamieszkania z obowiązkiem osiedlenia się w określonej miejscowości” (art. 24), wymierzane na okres do 5 lat;

1.3. wysiedlenie: „polega na wydaleniu skazanego z miejsca jego zamieszkania z zakazem zamieszkiwania w określonych miejscowościach" na okres do 5 lat (art. 24);

1.4. praca poprawcza bez pozbawienia wolności: wykonywana bądź w miejscu pracy, bądź w rejonie zamieszkiwania skazanego, z potrącaniem $\mathrm{z}$ wynagrodzenia do $20 \%$;

1.5. pozbawienie prawa zajmowania określonych stanowisk lub wykonywania określonej działalności na czas do 5 lat; mogło być karą zasadniczą albo dodatkową;

1.6. grzywna (art. 27): wymierzana w wysokości wskazanej w konkretnych przepisach karnych, „w zależności od wagi popełnionego przestępstwa z uwzględnieniem sytuacji materialnej sprawcy", najczęściej w wysokości od 50 do 300 rubli, wyjątkowo do 1000 rubli; zamiana grzywny na karę pozbawienia wolności była niedopuszczalna;

1.7. nagana społeczna: „polega na publicznym udzieleniu przez sąd nagany sprawcy z podaniem o tym w koniecznych wypadkach do publicznej wiadomości w prasie lub w inny sposób” (art. 28);

1.8. skierowanie do karnej kompanii: tylko wobec wojskowych w służbie czynnej.

2. Kary dodatkowe: oprócz wymienionych kar zasadniczych, można było $\mathrm{w}$ przypadkach wskazanych $\mathrm{w}$ ustawie stosować następujące kary dodatkowe:

2.1. konfiskata mienia: tylko $\mathrm{w}$ przypadkach wskazanych $\mathrm{w}$ ustawie $\mathrm{za}$ przestępstwa przeciwko państwu i ciężkie przestępstwa popełnione $\mathrm{z}$ chęci zysku mogła być orzeczona konfiskata całości lub części mienia;

2.2. pozbawienie stopnia wojskowego albo tytułu specjalnego.

W stosunku do stanu poprzedniego kodeks karny RSFRR z 1960 r. znosił 12 rodzajów kar ${ }^{49}$.

Kara śmierci nie została wymieniona w katalogu, ale pojawiła się zaraz w następnym artykule (art. 22) Podstaw... i analogicznie w kodeksie (art. 23 k.k.) $\mathrm{z}$ mocnym zaakcentowaniem, że jest to kara wyjątkowa. Stosowana miała być według Podstaw... oraz k.k. RSFRR z 1960 r. - za ciężkie przestępstwa wymienione w tym przepisie „oraz inne” przewidziane w ustawach ZSRR; katalog był więc otwarty. Wykonywana przez rozstrzelanie.

${ }^{49}$ W. E. Butler, Soviet Law..., s. 267. 
Historia kary śmierci ${ }^{50} \mathrm{w}$ radzieckim prawie formalnie przedstawia się tak:

\begin{tabular}{|c|c|}
\hline 25 marca 1917 & zniesienie kary śmierci (Rząd Tymczasowy) \\
\hline lipiec 1917 & przywrócenie jej wobec dezerterów na froncie \\
\hline $\begin{array}{l}10 \text { listopada/ } 28 \\
\text { października } 1917^{51}\end{array}$ & $\begin{array}{l}\text { zniesienie kary śmierci uchwałą II Wszechzwiązkowego } \\
\text { Zjazdu Rad }\end{array}$ \\
\hline 21 lutego 1918 & przywrócenie kary śmierci \\
\hline 17 stycznia 1920 & zniesienie kary śmierci \\
\hline 4 maja 1920 & przywrócenie kary śmierci \\
\hline 26 maja 1947 & zniesienie kary śmierci w czasie pokoju \\
\hline 12 stycznia 1950 & przywrócenie kary śmierci za zdradę kraju, szpiegostwo, dywersję \\
\hline 30 kwietnia 1954 & przywrócenie kary śmierci za umyślne zabójstwo \\
\hline 25 grudnia 1958 & $\begin{array}{l}\text { w ustawie o odpowiedzialności karnej za przestępstwa przeciwko } \\
\text { państwu przewidziano kary śmierci za następujące czyny: zdrada } \\
\text { ojczyzny, szpiegostwo, sabotaż i dywersja, akty terroru, bandytyzm, } \\
\text { umyślne zabójstwo; w czasie wojny oraz w warunkach działań } \\
\text { bojowych karę śmierci można było stosować także w wypadkach } \\
\text { innych ciężkich przestępstw. Ustawa ta weszła do kodeksów } \\
\text { republikańskich }\end{array}$ \\
\hline 5 maja 1961 & $\begin{array}{l}\text { stosowanie kary śmierci zostało rozszerzone na sprzeniewierzenie } \\
\text { mienia społecznego „w szczególnie wielkim rozmiarze” oraz za } \\
\text { zawodowe fałszowanie pieniędzy }\end{array}$ \\
\hline 1 lipca 1961 & $\begin{array}{l}\text { rozszerzenie kary śmierci za spekulację dewizami w znacznych } \\
\text { rozmiarach }\end{array}$ \\
\hline 15 lutego 1962 & $\begin{array}{l}\text { rozszerzenie kary śmierci na przestępstwa: zamach na życie } \\
\text { funkcjonariuszy milicji; gwałt w szczególnie obciążających } \\
\text { okolicznościach }\end{array}$ \\
\hline 20 lutego 1962 & $\begin{array}{l}\text { rozszerzenie stosowania kary śmierci na przestępstwo } \\
\text { przekupstwa urzędników }\end{array}$ \\
\hline 3 września 1965 & $\begin{array}{l}\text { wprowadzono karę śmierci za zabójstwa i tortury dokonywane } \\
\text { w czasie II wojny }\end{array}$ \\
\hline 3 stycznia 1973 & przewidziano karę śmierci za porwanie samolotu \\
\hline
\end{tabular}

Historia Rosji radzieckiej i ZSRR pokazuje jednak, że powtarzające się decyzje o zniesieniu kary śmierci nosiły w znacznym stopniu charakter polityczno-propagandowy, zwłaszcza w najwcześniejszym okresie wojny domowej. To jeden z powszechnie spotykanych przypadków drastycznej rozbieżności między oświadczeniami i prawem na papierze a rzeczywistością ${ }^{52}$; „totalne kłamstwo” to jedna z cech czerwonego totalitaryzmu (L. Kołakowski). Zaliczenie statystyk kry-

${ }^{50}$ Zob. K. Laskowska, Kara śmierci w Rosji w świetle prawa i praktyki wymiaru sprawiedliwości na przestrzeni wieków, „Miscellanea Historico-Iuridica”, Białystok, tom 7 (w druku).

${ }^{51}$ Należy sprostować datę podawaną powszechnie w literaturze przedmiotu, jakoby nastąpiło to 8 listopada/26 października. Zob. Об отмене смертной казни. СУ РСФСР 1917, № 1, ст. 4, 2-е издание.

${ }^{52}$ Zob. A. Bosiacki, Utopia - władza - prawo..., s. 236. Patrz też P. H. Juviler, Revolutionary Law..., s. 172. 
minologicznych do tajemnicy państwowej uniemożliwia wiarygodne określenie rozmiarów praktyki skazywania na karę najwyższą oraz jej wykonywania ${ }^{53}$.

Przewidziane więc były dwie formy odbywania kary pozbawienia wolności: w obozach pracy poprawczej albo w więzieniach ${ }^{54}$; tę drugą stosowano zwłaszcza wobec przestępców szczególnie niebezpiecznych, wielokrotnych recydywistów. Wrócono do zasady sprzed 1957 r., że kara pozbawienia wolności wymierzana jest do lat 10, ale przecież z licznymi wyjątkami w kierunku dłuższego okresu, co czyniło zasadę mocno iluzoryczną. Podstawy... nigdzie nie określały natomiast dolnej granicy kary pobawienia wolności, pozostawiając taką możliwość kodeksom republikańskim ${ }^{55}$.

Zgodnie z prawem (Podstawy..., art. 32 i k.k. RSFRR art. 37 i n.) sąd miał wymierzać karę w granicach ustawy, „kierując się socjalistyczną świadomością prawną", uwzględniać stopień niebezpieczeństwa społecznego, osobowość sprawcy oraz okoliczności łagodzące i obciążające, bliżej zresztą w następnych artykułach sprecyzowane. Było to europejskie unormowanie klasyczne, bez akcentów pozytywistycznych. Poważne zaostrzenia wymiaru kary miały miejsce w przypadku recydywy. Był to też jeden z elementów dyferencjacji represji karnej, podobnie jak rozbudowane przepisy o warunkowym przedterminowym zwolnieniu od kary (art. 53 k.k. RSFRR), o uwolnieniu od odpowiedzialności karnej (art. 50-52 k.k. RSFRR), wymierzeniu kary łagodniejszej od przewidzianej w ustawie (art. 43 k.k. RSFRR), warunkowe skazanie (art. 44 k.k. RSFRR) oraz wprowadzona nieco później (1970 r.) nowa instytucja: warunkowe skazanie z nałożeniem obowiązku wykonywania określonej pracy; środek ten przeznaczony był do eliminowania kar krótkoterminowych i zdobył sobie znaczną popularność.

3. Przechodząc do wybranych zagadnień z części szczegółowej radzieckiego prawa karnego warto zauważyć, że w tej części silniej zaznaczał się dwuwarstwowy charakter prawa: federalny i republikański. Przepisy karne ogólnozwiązkowe (federalne) konstruowały przestępstwa antypaństwowe i wojskowe, wyjątkowo także niektóre inne (wspomniana tendencja rozszerzającej interpretacji, jakie sprawy należały do regulacji federalnej). Te przepisy były najczęściej wprost inkorporowane do ustawodawstw (kodeksów) poszczególnych republik. Większość materii części szczegółowej prawa karnego składała się jednak z przepisów

${ }^{53}$ Obserwacje pozwoliły ustalić, że w czasie 12 miesięcy na przełomie lat 1961-1962 w ZSRR wykonano ponad 250 egzekucji (dla porównania: w USA w tym samym czasie 43). H. J. Berman, Justice in the U.S.S.R..., s. 86.

${ }^{54}$ W. E. Butler, Soviet Law..., s. 267; zob. także F. J. M. Feldbrugge, Soviet Corrective Labor Law..., s. 36,41 .

${ }^{55}$ P. S. Romaszkin, A. A. Gercenzon, Podstawy ustawodawstwa karnego ZSRR republik zwiazkowych, [w:] Problemy radzieckiego prawa karnego. Wybór z literatury radzieckiej, Warszawa 1962, s. 91. 
republikańskich. Nie ma powodów omawiania całości, toteż poniżej tylko wybrane zagadnienia.

Jak wspomniano, systematyka wszystkich kodeksów republikańskich była podobna ${ }^{56}$. Wszędzie rozdział I to uregulowane federalnie przestępstwa przeciwko państwu, zresztą z wydzielonym podrozdziałem „szczególnie niebezpieczne przestępstwa przeciwko państwu" (tu m.in. zdrada ojczyzny, szpiegostwo, akty terrorystyczne i inne) oraz „inne przestępstwa przeciwko państwu” (tu m.in. naruszenie tajemnicy państwowej, bandytyzm, przemyt, rozruchy i inne). Warto zauważyć, iż zrezygnowano z wcześniejszej odpowiedzialności zbiorowej członków rodziny sprawcy. W porównaniu do kodeksu z 1926 r. znacznie złagodzono sankcje za niedoniesienie o przestępstwie przeciwko państwu. Nie było już przestępstw związanych z pełnieniem zadań w „aparacie carskim”. Był natomiast $\mathrm{w}$ rozdziale I przepis o antyradzieckiej agitacji i propagandzie ${ }^{57}$ (złagodzone sankcje). Łącznie rozdział I k.k. RSFRR liczył 25 artykułów. Generalnie regulacje rozdziału I o przestępstwach przeciwko państwu zbliżały się do podobnych rozwiązań europejskich. W rozdziale I były też przepisy dotyczące ochrony sfery gospodarczej państwa, chociaż przestępstwom gospodarczym poświęcono odrębnie rozdział VI, a w nim także znalazły się takie przestępstwa, jak „przejawianie prywatnej inicjatywy i pośrednictwo handlowe”, czy spekulacja (art. 153-155). Nie może zaskakiwać, że na drugim miejscu, tzn. w rozdziale II, znalazły się „przestępstwa przeciwko własności socjalistycznej” (art. 89-101 k.k. RSFRR). Regulacja była nad wyraz kazuistyczna, różnicująca odpowiedzialność w zależności od form i sposobów działania, współsprawstwa, form zagarnięcia mienia, form bezprawnego korzystania z mienia społecznego, zajmowanego przez sprawcę stanowiska służbowego, wartości mienia, wielkości wyrządzonej szkody i inne. Natomiast „przestępstwa przeciwko własności osobistej obywateli” umieszczono nie tylko odrębnie (rozdział V), ale także znacznie dalej. Znamienne, że przepisy karne całego rozdziału konsekwentnie zawierały w swych dyspozycjach mienie „osobiste”, a nie było w ogóle przepisów chroniących mienie prywatne obywateli, nie będące mieniem osobistym. W rozdziale III umieszczono „przestępstwa przeciw życiu, zdrowiu, wolności i godności jednostki”. Podobnie kazuistycznie uregulowano liczne przestępne stany faktyczne, w tym zabójstwo, siedem form uszkodzenia ciała, zgwałcenie (kobiety, nie mężczyzny) karane bardzo surowo, stosunki homoseksualne między mężczyznami (nie kobietami), oszczerstwo, zniewagę i wiele innych. Wśród przestępstw „przeciw wymiarowi sprawiedliwości" (rozdział VIII) zwraca uwagę wysunięcie na plan pierwszy takich czynów, jak „pociągnięcie do odpowiedzialności karnej przez prowadzącego dochodzenie, śledztwo lub prokuratora osoby, której niewinności sprawca jest świadom”, przy czym postacią kwalifikowaną były „te same czyny połączone z oskarżeniem

\footnotetext{
${ }^{56}$ Inaczej W. E. Butler, Soviet Law..., s. 271.

${ }^{57}$ W. E. Butler, Soviet Law..., s. 271-272.
} 
o popełnienie szczególnie niebezpiecznego przestępstwa przeciw Państwu lub o inne ciężkie przestępstwo albo tworzeniem fikcyjnych dowodów oskarżenia" (art. 176 k.k. RSFRR). Inne to „wydanie przez sędziów świadomie niepraworządnego wyroku, orzeczenia lub postanowienia" z dodatkiem postaci kwalifikowanej „jeżeli spowodowały poważne skutki” (art. 176 k.k. RSFRR); „świadome bezprawne aresztowanie” i takież zatrzymanie (art. 178 k.k. RSFRR); „zmuszanie za pomocą groźby lub innych bezprawnych czynów do złożenia zeznań, popełnione przez osobę prowadzącą dochodzenie lub śledztwo" z kwalifikowaną postacią $\mathrm{W}$ razie stosowania przemocy lub znęcania się nad przesłuchiwaną osobą (art. 179 k.k. RSFRR). Komentarze są zbyteczne, bo w oczy rzuca się odreagowanie procesów stalinowskich, których ofiarami padali także najwybitniejsi bolszewicy i nikt, nawet najwyższy dostojnik i funkcjonariusz, nie był wolny od strachu. Osobny rozdział (XII w k.k. RSFRR) to „przestępstwa wojskowe”, których podmiotem mógł być tylko żołnierz lub osoba obowiązana do służby wojskowej oraz funkcjonariusze organów bezpieczeństwa (art. 237 k.k. RSFRR). Były to typowo wojskowe przestępstwa, jak nieposłuszeństwo, niewykonanie rozkazu, dezercja, kazuistycznie uregulowane naruszenia regulaminów, przestępstwa na polu walki itp. Liczba zagrożeń karą śmierci za te przestępstwa uległa zmniejszeniu, a ponadto zlikwidowano bezwzględnie określone w ustawie kary śmierci, zastępując je alternatywnymi ${ }^{58}$.

4. Ustawodawstwo karne $\mathrm{z}$ lat 1958-1961 stanowiło przełom w dotychczasowym systemie prawa karnego ZSRR i po raz pierwszy od 1917 r. zbliżyło radzieckie prawo karne do standardów europejskich przez wsparcie go na podstawach legalistycznych i zbliżenie do rozwiązań neoklasycznych. Przy licznych nowelizacjach, wymienione akty prawne przetrwały dłużej aniżeli do końca istnienia Związku Radzieckiego, tworząc w istocie nowy system radzieckiego prawa karnego. Nie zapobiegło to nawrotowi surowej polityki kryminalnej i karania $\mathrm{w}$ trybie administracyjnym ${ }^{59}$, ale do czasów stalinowskich powrotu nie było.

Wraz z "pierestrojką" wysuwano program reform, ale i stabilizacji prawa karnego. Nowe ustawodawstwo karne ostatnich około 6 lat istnienia Związku Radzieckiego było liczebnie dość duże, ale generalnie - mimo krytyki - trwał stan sprzed „pierestrojki”, czyli wsparty na Podstawach... z 1958 r. oraz kodeksach z lat 1959-1961 z licznymi późniejszymi zmianami. Tymczasem nowa ekonomika i tworzenie się sektora prywatnego spowodowały wzrost przestępczości ${ }^{60}$.

\footnotetext{
${ }^{58}$ N. W. Wasiliew, W. N. Kudriawcew, Ustawa o odpowiedzialności karnej za przestępstwa wojskowe, [w:] Problemy radzieckiego prawa karnego. Wybór z literatury radzieckiej, Warszawa 1962, s. 128.

${ }^{59}$ H. J. Berman, Justice in the U.S.S.R..., s. 84 i n.

${ }^{60}$ P. H. Solomon, Jr., Reforming Criminal Law under Gorbachev. Crime, Punishment, and the Rights of the Accused, [w:] Toward the "Rule of Law" in Russia? Political and Legal Reform in the Transition Period, ed. by D. D. Barry, New York-London [1992], s. 235.
} 
Ważny zwrot miał miejsce dopiero w 1988 r., kiedy to na konferencji KPZR przełamano istniejącą siedem dekad tradycję polityczną i prawną ${ }^{61}$. Podjęto prace przygotowujące nowe Podstawy ustawodawstwa karnego Związu SRR i republik związkowych oraz nowy kodeks karny [уголовный закон] Federacji Rosyjskiej. Dyskusje nad reformą prawa karnego objęły kręgi akademickie ${ }^{62}$. Nie wchodząc w szczegóły: prace nad kodeksem karnym przed likwidacją ZSRR nie zostały ukończone. Nowy kodeks karny Rosyjskiej Federacji wszedł w życie w 1996 r. $^{63}$

Natomiast prace nad Podstawami ustawodawstwa karnego Związku SRR i republik związkowych zostały sfinalizowane (wszak to tylko rodzaj części ogólnej) i nowe Podstawy... zostały w 1991 r. przyjęte ${ }^{64}$ oraz weszły w życie w miejsce uchylonych Podstaw... z 1958 r. ${ }^{65}$ Znacznie obszerniejsze od Podstaw... z 1958 r. $\mathrm{w}$ swojej wewnętrznej strukturze i wielu rozwiązaniach bliższe wspomnianemu poprzednio projektowi kodeksu aniżeli dawnemu prawu radzieckiemu, jednak w równie wielu rozwiązaniach i koncepcjach do dawnego ducha nowe Podstawy... nawiązywały. Podstawy ustawodawstwa karnego Zwiazku SRR i republik związkowych z $1991 \mathrm{r}$. były prawdziwie nowe i nowoczesne, idące w kierunku umacniania legalizmu i praworządności, ale jednak daleko im było do nowatorstwa i ducha wolności, jaki ożywiał nieukończony w ZSRR projekt kodeksu karnego. Uchwalone tuż przed końcem istnienia Związku Socjalistycznych Republik Radzieckich Podstawy ustawodawstwa karnego Związu SRR i republik związkowych mogły już tylko zostać pomnikiem historycznym.

${ }^{61}$ E. Huskey, From Legal Nihilism to Pravovoe Gosudarstvo. Soviet Legal Development, 1917-1990, [w:] Toward the Rule of Law in Russia? Political and Legal Reformi in the Transition Period, ed. by D. D. Barry, New York-London [1992], s. 33.

${ }^{62}$ P. H. Solomon, Jr., Reforming Criminal Law under Gorbachev..., s. 235 i n.

${ }^{63} \mathrm{http}: / /$ www.lawru.info, dostęp: styczeń 2009.

${ }^{64}$ Ведомости СНД СССР, 1991, № 30, поз. 862.

${ }^{65}$ История отечественного государства и права, ч. 2, четвертое издане, переработанное и дополненное, авторский коллектив под редакцией О. И. Чистякова, Москва 2006, s. 473. Szczegółowo zob. P. H. Solomon, Jr., Reforming Criminal Law under Gorbachev..., s. 241-250. 